\title{
MANAJEMEN PROSES BISNIS UNTUK INSTITUT TEKNOLOGI KALIMANTAN
}

\author{
Lovinta Happy Atrinawati ${ }^{1 *}$, Wiratama Putra Pratikta ${ }^{1}$ \\ ${ }^{1}$ Program Studi SISTEM INFORMASI, Institut Teknologi Kalimantan \\ Jl Soekarno Hatta KM 15, Balikpapan, Kalimantan Timur 76127.
}

\begin{abstract}
Abstrak
Proses bisnis memiliki peran krusial untuk memastikan organisasi, termasuk universitas, mampu mencapai tujuannya. Institut Teknologi Kalimantan (ITK) sebagai universitas berkembang belum memiliki model proses bisnis atau Standar Operasional Prosedur (SOP). Hal ini menyebabkan tidak terstandarisasinya proses yang berjalan dan terjadinya deviasi untuk setiap proses yang terjadi di ITK. Penelitian ini bertujuan untuk mengembangkan model proses bisnis akademik ITK dan untuk memastikan bahwa proses bisnis sesuai dengan standar yang berlaku, yaitu Standar Nasional Pendidikan Tinggi (SNPT) dan Badan Akreditasi Nasional Perguruan Tinggi (BAN-PT). Pendekatan yang digunakan dalam penelitian ini meliputi business process management, tahapannya meliputi process identification, process discovery, process analysis, dan process redesign. Setelah mengidentifikasi proses bisnis pada bidang akademik, dilakukan pemodelan proses bisnis saat ini (as-is) menggunakan notasi Business Process Model and Notation (BPMN). Dari hasil pemodelan tersebut kemudian dilakukan analisis kesesuaian untuk mengetahui proses bisnis yang belum sesuai dengan standar dan kelemahan yang terjadi ketika terus dijalankan. Berdasarkan analisis proses didapatkan 16 isu pada 13 proses bisnis yang tidak sesuai dengan standar beserta kelemahannya. Hasil analisis kemudian digunakan sebagai usulan rekomendasi dengan memodelkan proses bisnis yang akan datang (to-be) yang telah sesuai dengan standar, sehingga terdapat 5 proses baru, 3 diperbaiki, dan 1 dihapus. Model proses ini diverifikasi oleh Kepala Penjaminan Mutu ITK dan diharapkan dapat digunakan sebagai referensi untuk pengembangan SOP akademik di ITK
\end{abstract}

Kata kunci: proses bisnis, business process management, pendidikan tinggi, BPMN

\section{PENDAHULUAN}

Setiap organisasi, termasuk lembaga pendidikan tinggi, memiliki proses bisnis untuk mengelola dan memberikan produk atau layanan kepada pelanggannya. Proses bisnis ada sekumpulan aktivitas yang menerima satu jenis atau lebih input kemudian menghasilkan output yang bernilai bagi organisasi (Dumas, et al., 2018). Setiap organisasi memiliki proses bisnis yang berisi rangkaian aktivitas untuk menghasilkan suatu produk atau layanan sebagai hasil akhirnya (Ouali, et al., 2016). Proses bisnis bukan hanya sebagai alat untuk menjadi standar berjalannya sebuah organisasi, namun juga menjadi faktor penentu kelancaran, performa, dan keberhasilan sebuah organisasi (Falahah, 2012). Proses bisnis terdiri dari sekelompok tugas-tugas yang saling berhubungan dan memanfaatkan sumber daya dari organisasi untuk mencapai suatu hasil yang diinginkan dalam mendukung organizations process (Harrington, 1991).

Pemetaan proses bisnis di Perguruan tinggi negeri diwajibkan untuk melaksanakan misi Kementrian Riset Teknologi, dan
Pendidikan Tinggi yaitu mewujudkan tata kelola pemerintahan yang baik dalam rangka reformasi birokrasi. Peraturan Menteri Riset, Teknologi, dan Pendidikan Tinggi Republik Indonesia Nomor 71 Tahun 2017 pasal 3 ayat (2) menyebutkan bahwa perguruan tinggi negeri wajib membangun menata, menyusun, melaksanakan, dan mengevaluasi peta proses bisnis dan standard operasional bisnis (Kementrian Riset, Teknologi, dan Pendidikan Tinggi, 2017). Model proses bisnis di lembaga pendidikan tinggi harus memperhatikan efektivitias dan efisiensi dari hubungan kerja antar unit organisasi. Dengan memodelkan proses bisnis, universitas atau lembaga pendidkan tinggi dapat mengidentifikasi, mendokumentasikan, mengkomunikasikan permasalahan (seperti bottlenecks, critical path, atau antrian) secara sistematis kepada para stakeholders (Ramdani, 2015). Sebagai salah satu perguruan tinggi negeri di Balikpapan, Institut Teknologi Kalimantan (ITK) tentunya wajib untuk memenuhi peraturan tersebut. Namun, saat ini ITK belum mempunyai standar operasional baku dan belum memiliki 
dokumentasi proses bisnis yang ada. Proses bisnis yang dilakukan oleh ITK ITK masih dalam tingkat kematangan 2 (repeatable) yang menunjukkan bahwa proses bisnis di ITK belum terkoordinasi dan belum terstruktur (Ahern, et al., 2008). Merujuk pada permasalahan ini, maka dibutuhkan permodelan proses bisnis di ITK.

Penelitian ini akan fokus pada proses bisnis akademik yang akan dilakukan di itk. Proses bisnis saat ini akan dimodelkan menggunakan BPMN. Proses tersebut akan dianalisas kesesuaiannya dengan standar yang berlaku, yaitu Standar Nasional Pendidikan Tinggi (SNPT) (Kementerian Riset, 2015) dan kriteria pendilaian Badan Akreditasi Nasional Pendidikan Tinggi (BAN PT) (Badan Akreditasi Nasional Perguruan Tinggi (BANPT), n.d.). selanjutkan, dilakukan perancangan ulang (redesign) untuk memastikan bahwa proses bisnis yang akan diimplementasikan di ITK (dalam bentuk SOP) telah sesuai dengan tujuan yang ingin dicapai dalam penelitian ini antara lain mengidentifikasi dan menghasilkan proses bisnis bidang akademik yang saat ini terjadi di ITK, menganalisis model proses bisnis bidang akademik yang saat ini terjadi di ITK, serta menghasilkan usulan model proses bisnis bidang akademik yang sesuai dengan standar dan dapat diterapkan di ITK.

\section{METODE}

Metodologi yang digunakan dalam penelitian ini mengadopsi siklus hidup manajemen proses bisnis yang dikemukakan oleh Dumas, dkk (Dumas, et al., 2018).

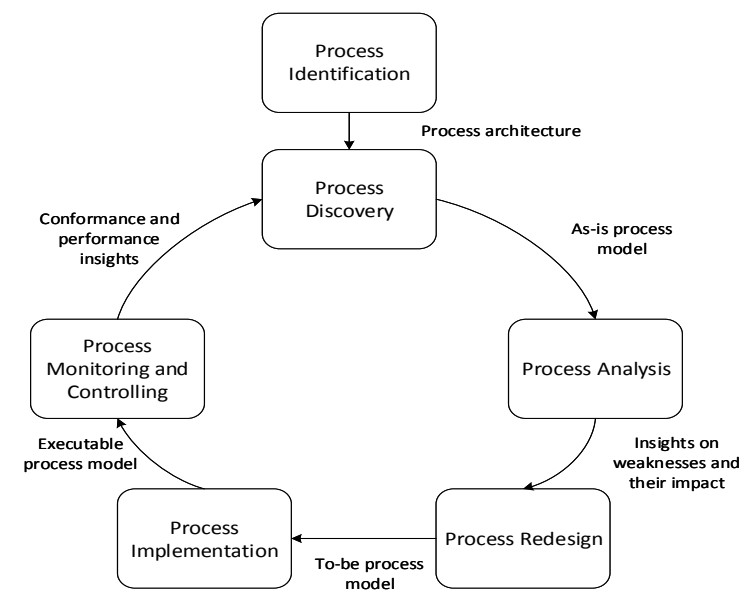

Gambar 1. Siklus hidup Business Process Management
Tahapan dalam merancang proses model bagi ITK adalah sebagai berikut:

\section{Process Identification}

Identifikasi terhadap proses-proses utama khususnya di bidang akademik dilakukan dengan pendekatan reference model. Dalam penelitian ini, digunakan acuan berupa APQC PCF (American Productivity and Quality Center Process Classification Framework) for education (APQC, 2014) yang kemudian dirancang menjadi sebuah process architecture. Process architecture ini kemudian diverifikasi melalui wawancara dengan Ketua Pusat Penjaminan Mutu ITK.

\section{Process Discovery}

Pengumpulan informasi mengenai proses bisnis yang terjadi dilakukan, khususnya di bidang akademik. Terdapat tiga metode yang dapat dilakukan untuk mengumpulkan informasi, yaitu evidence-based discovery dan interview-based discovery. Evidence-based discovery dilakukan dengan cara mengkaji dokumen-dokumen ITK seperti struktur organisasi dan panduan yang berhubungan dengan bidang akademik. Setelah itu dilakukan interview-based discovery dengan wawancara kepada pihak terkait, seperti ketua pusat penjaminan mutu ITK, koordinator program studi, dosen, tenaga kependidikan, mahasiswa, dan stakeholder lainnya. Setelah melakukan pengumpulan informasi, maka didapatkan tahapan-tahapan dalam melakukan aktivitas pada proses-proses yang ada di dalam bidang pendidikan, kemudian dilakukan pemodelan dengan notasi Business Process Model Notation (BPMN). Pemodelan proses bisnis as-is ini dilakukan untuk mendapatkan visualisasi dari proses bisnis di bidang pendidikan yang terjadi di ITK. Verifikasi dilakukan setelah memodelkan proses bisnis as-is, yaitu dengan dengan pemeriksaaan model dan konfirmasi oleh pusat penjaminan mutu ITK. Tujuan melakukan verifikasi adalah untuk memastikan kebenaran dari model proses bisnis as-is yang telah dibuat.

\section{Process Analysis}

Analisis kesesuaian terhadap proses model as-is dilakukan untuk mendapatkan kesenjangan yang terjadi diantara model tersebut. Analisis kesesuaian ini dilakukan dengan mencari dimanakah aktivitas atau proses yang tidak ada pada model as-is tetapi ada di SNPT dan BAN-PT. Dari analisis kesesuaian yang dilakukan kemudian didapatkan daftar perbedaan apa saja yang dibutuhkan untuk pembuatan strategi 
penyesuaian dalam penelitian ini dalam bentuk proses model to-be.

\section{Process Redesign}

Dari hasil analisis, kemudian dibuat rekomendasi dengan cara memodelkan proses bisnis to-be. Pemodelan proses bisnis to-be dilakukan berdasarkan kesesuaian dengan standar dimana kesesuaian organisasi mengacu pada SNPT dan BAN-PT. Maka dari itu untuk melakukan pemodelan proses bisnis to-be ini perlu dilakukan analisis dan pengkajian terhadap dokumen yang membahas mengenai proses bisnis di bidang akademik. Pemodelan proses bisnis to-be dengan notasi BPMN dilakukan setelah mendapatkan tahapan dalam aktivitas proses bisnis bidang akademik. Verifikasi dilakukan setelah memodelkan proses bisnis to-be, yaitu dengan dengan pemeriksaaan model dan konfirmasi oleh pusat penjaminan mutu ITK. Tujuan melakukan verifikasi adalah untuk penyelarasan proses bisnis to-be yang telah dibuat dengan kebutuhan ITK.

Pada penelitian ini tidak melakukan process implementation dan process monitoring and controlling

\section{HASIL DAN PEMBAHASAN}

\subsection{Process Identification}

Pada tahap process identification menjelaskan mengenai tahap mengidentifikasi proses bisnis bidang akademik di ITK. Proses ini dilakukan dengan menggunakan acuan APQC PCF for education (APQC, 2014) yang dijelaskan pada Gambar 2. Proses utama untuk lembaga pendidikan tinggi (universitas) meliputi:

1. Develop Vision and Strategy

2. Develop, Deliver, and Assess Curriculum, Assessment, and Instruction

3. Design and Deliver Student Support Services

4. Design and Manage Operations

5. Manage Student and stakeholder Relationship and Engagement

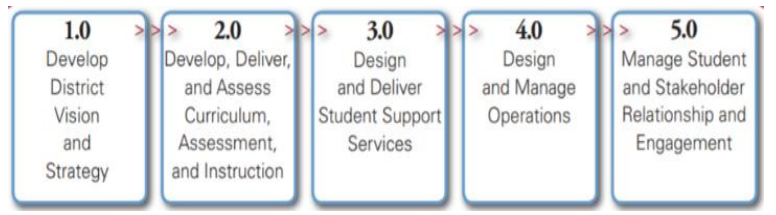

Gambar 2. Proses utama APQC PCF for Education

Berdasarkan hasil wawancara dengan ketua pusat penjaminan mutu ITK, process architecture yang telah dibuat belum sesuai dengan kondisi yang terjadi di ITK. Maka dari itu process architecture yang telah dibuat kemudian didetailkan lagi untuk memastikan bahwa seluruh proses bisnis akademik di ITK telah dicakup dalam process architecture. Pedoman tersebut yaitu dengan mengidentifikasi awal dan akhir dari sebuah proses dengan mengidentifikasi awal dan akhir dari transaksi yang sesuai, sehingga dimulai pada saat penyusunan kurikulum hingga mahasiswa wisuda. Process architecture tersebut ditransformasikan ke dalam proses model menggunakan BPMN, seperti pada Gambar 3.

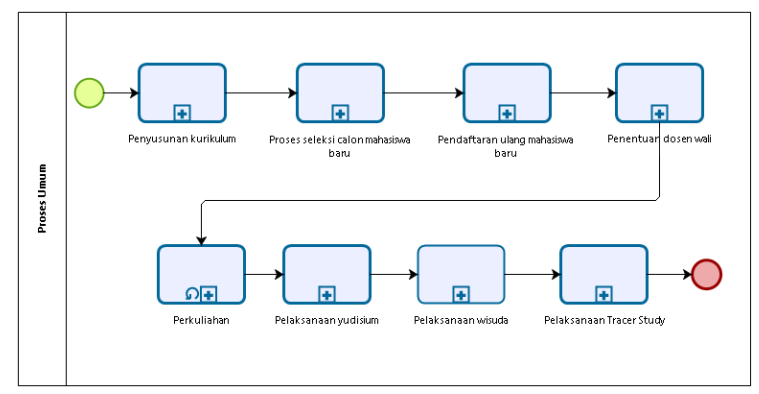

Gambar 3 Gambaran umum proses akademik ITK

\section{2. $\quad$ Process Discovery}

Pada tahap ini dilakukan pengumpulan informasi mengenai proses bisnis yang terjadi khususnya di bidang akademik. Tahapan ini dilakukan dengan dua metode, yaitu evidence-based discovery dan interview-based discovery.

Process discovery adalah tahap mendetailkan arsitektur proses yang kemudian dimodelkan menjadi as-is business process model. Tahap ini dilakukan dengan cara mewawancarai process owner, observasi, dan walkthrough. Setelah informasi detail terkait proses akademik didapatkan, maka aktivitas pada proses akademik dimodelkan dengan notasi BPMN. Verifikasi dilakukan setelah memodelkan proses bisnis as-is, yaitu dengan dengan pemeriksaaan model dan konfirmasi oleh pusat penjaminan mutu ITK.

Setelah dilakukan tahapan process discovery, kemudian proses bisnis didetailkan dan digambarkan model proses bisnisnya. Hasil dari pemodelan proses bisnis didapatkan 1 proses model utama akademik ITK dan sebanyak 33 model proses akademik saat ini (as-is). Pada artikel ini, hasil permodelan proses bisnis as is akademik di Institut Teknologi Kalimantan tidak akan ditampilkan. Setelah dilakukan pemodelan proses bisnis saat ini (as-is), dilakukan verifikasi 
kepada Ketua Pusat Penjaminan Mutu ITK. N Contoh model proses bisnis yang telah o diverifikasi dapat dilihat pada Gambar 4.

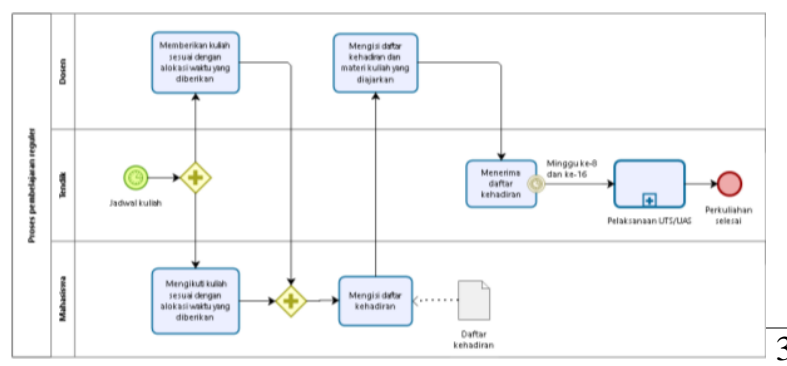

\subsection{Process Analysis}

Analisis kesesuaian terhadap regulasi dan kelemahan yang terdapat pada proses bisnis akademik saat ini as-is kemudian dilakukan setelah pemodelan proses as-is. Analisis ini mengacu kepada proses model as-is dan reference model. Berdasarkan hasil wawancara dengan ketua pusat penjaminan mutu ITK, didapatkan bahwa saat ini ITK sedang menyusun prosedur operasional baku dengan merujuk kepada SNPT dan BAN-PT. Maka dari itu pada tahap process analysis dan process redesign menggunakan acuan berupa SNPT dan BAN-PT. Analisis kesesuaian dilakukan untuk mengetahui apakah proses model as-is telah sesuai dengan standar atau tidak. Tabel 1 merupakan daftar hasil analisis proses model as-is setelah dibandingkan dengan SNPT, BAN-PT, hasil wawancara, dan observasi. Dari hasil analisis, ditemukan 16 isu pada 13 proses model as-is yang tidak sesuai terhadap standar.

\section{Tabel 1. Analisa kesesuaian proses bisnis as is dengan SNPT dan BAN PT}

\begin{tabular}{ll}
\hline $\mathbf{N}$ & \multicolumn{1}{c}{ Standar Acuan } \\
$\mathbf{0}$ & \multicolumn{1}{c}{ Stan } \\
\hline 1 & BAN PT poin 3.3.1 b \\
& Penggunaan hasil \\
& pelacakan untuk \\
& perbaikan: (1) proses \\
& pembelajaran, (2) \\
& penggalangan dana, \\
& (3) informasi pekerjaan, \\
& (4) membangun jejaring.
\end{tabular}

2 BAN PT poin 4.5.1

Kegiatan tenaga ahli/pakar (sebagai pembicara dalam seminar/pelatihan, pembicara tamu, dsb, dari luar PT sendiri (tidak termasuk dosen tidak tetap). $\mathbf{J}_{\mathrm{TAP}}=$ Jumlah

\section{Ketidaksesuaian}

Pelaksanaan tracer study tidak maksimal pemanfaatannya, karena tidak ada timbal balik berupa evaluasi dan perbaikan khususnya pada proses pembelajaran Visi ITK akan tidak tercapai karena selain proses pembelajaran yang dilakukan oleh dosen, ITK harus mampu menyerap ilmu dari tenaga ahli/pakar dari luar perguruan tinggi contohnya

\section{Standar Acuan}

tenaga ahli/pakar. Catatan: Tenaga ahli dari luar perguruan tinggi dengan tujuan untuk pengayaan pengetahuan dan bukan untuk mengisi kekurangan tenaga pengajar, tidak bekerja secara rutin. Jika $\mathbf{J}_{\mathrm{TAP}} \geq$ 12 orang, maka skor $=4$

\section{BAN PT poin 5.2.a}

Pelaksanaan peninjauan kurikulum selama 5 tahun terakhir

\section{BAN PT poin 5.3.1.a}

Pelaksanaan

pembelajaran memiliki memonitor, mengkaji, dan memperbaiki setiap semester tentang:

(a) kehadiran mahasiswa

(b) kehadiran dosen

(c) materi kuliah mekanisme untuk

\section{Ketidaksesuaian}

melalui seminar, pelatihan, kuliah tamu, dsb

Program studi akan

terhambat

pengembangannya bila tidak ada peninjauan ulang secara berkala Program studi tidak dapat menyediakan informasi yang relevan terhadap materi perkuliahan dan rencana pembelajaran. Selain itu program studi tidak dapat mengetahui apakah materi perkuliahan dan rencana pembelajaran yang dibuat telah sesuai dengan kurikulum

BAN PT poin 5.4.1.a Rata-rata banyaknya mahasiswa per dosen Pembimbing Akademik (PA) per semester (=RMPA)

6 BAN PT poin 5.4.1.c Jumlah rata-rata Dosen tidak dapat fokus membimbing mahasiswa jika melebihi kapasitas pertemuan pembimbingan per mahasiswa per semester (= PP)
BAN PT poin 5.5.1.b

Rata-rata mahasiswa per dosen pembimbing tugas akhir $\left(=\mathrm{R}_{\mathrm{MTA}}\right)$

8 SNPT Pasal 28 (3)

Beban kerja dosen sebagai pembimbing utama dalam penelitian terstruktur dalam rangka penyusunan skripsi/ tugas akhir atau bentuk lain yang setara paling banyak 10 (sepuluh) mahasiswa

9 BAN PT poin 5.5.1.c Rata-rata jumlah pertemuan/pembimbingan selama penyelesaian TA $\left(=\mathrm{R}_{\mathrm{BTA}}\right)$
Mahasiswa tidak dapat mengevaluasi terkait perkuliahan khususnya proses pembelajaran

Dosen tidak dapat fokus membimbing tugas akhir mahasiswa jika melebihi kapasitas dan Bidang Minat TA
Mahasiswa tidak siap untuk menyelesaikan TA jika tidak melakukan pertemuan/pembimbing an sesuai jumlah yang ditentukan 


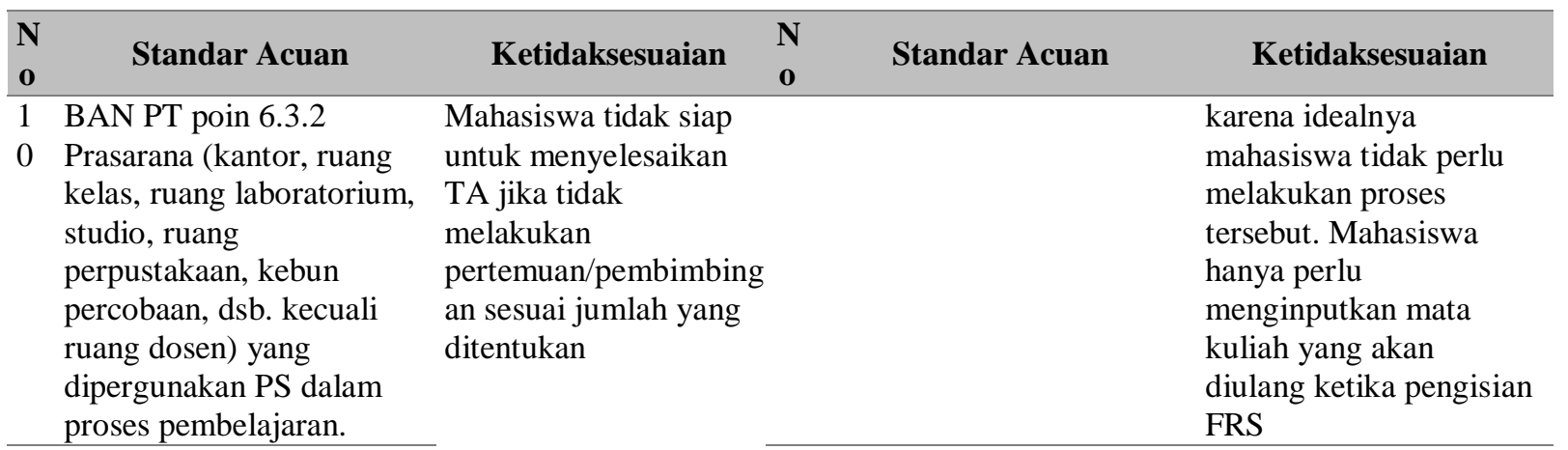

1 BAN PT poin 6.4

1 Akses dan pendayagunaan sarana yang dipergunakan dalam proses administrasi dan pembelajaran serta penyelenggaraan kegiatan Tridharma PT secara efektif.

1 BAN PT poin 6.5.1

2 Sistem informasi dan fasilitas yang digunakan PS dalam proses pembelajaran (hardware, software, e-learning, perpustakaan, dll.)

1 BAN PT poin 6.5.2

3 Aksesibilitas data dalam sistem informasi

Penilaian didasarkan atas aturan berikut:

1: Data ditangani secara manual

2: Data ditangani dengan komputer tanpa jaringan 3: Data ditangani dengan komputer, serta dapat diakses melalui jaringan lokal (LAN)

4: Data ditangani dengan komputer, serta dapat diakses melalui jaringan luas (WAN)

1 SNPT pasal 24

4 Hasil penilaian diumumkan kepada mahasiswa setelah tahap pembelajaran sesuai dengan rencana pembelajaran

1 Hasil wawancara Ketua

5 Penjaminan Mutu ITK Perlu ditambahkan evaluasi atau kendali soal

1 Hasil wawancara Ketua

6 Penjaminan Mutu ITK
Ketika sebuah proses ditangani secara manual dengan tidak terhubung ke sistem, maka proses yang dilakukan memakan waktu yang cukup lama dan aksesibilitas terbatas.

Mahasiswa tidak dapat memperkirakan nilai akhir

Soal yang telah dibuat tidak sama pembobotannya dan terjadi gap nilai pada dosen di mata kuliah yang sama

Nilai mata kuliah berpotensi redundan,

\subsection{Process Redesign}

Dari hasil analisis kemudian pada tahap process redesign dibuat rekomendasi dengan cara memodelkan proses bisnis to-be dengan notasi BPMN. Contoh untuk proses model as-is yaitu Pelaksanaan Tracer Study yang mulanya kuesioner masih dibuat secara manual dan menggunakan kuesioner hanya sebagai keperluan evaluasi kurikulum, seperti yang ditunjukkan pada Gambar 5. Dari hal tersebut kemudian diusulkan rekomendasi pada proses model to-be, yaitu Pelaksaan Tracer Study dibagi menjadi 2 proses yang berbeda yaitu Pelaksanaan Survey Alumni dan Pelaksanaan Survey Pengguna Alumni. Usulan proses model to-be dapat dilihat pada Gambar 6 sampai Gambar 8 .

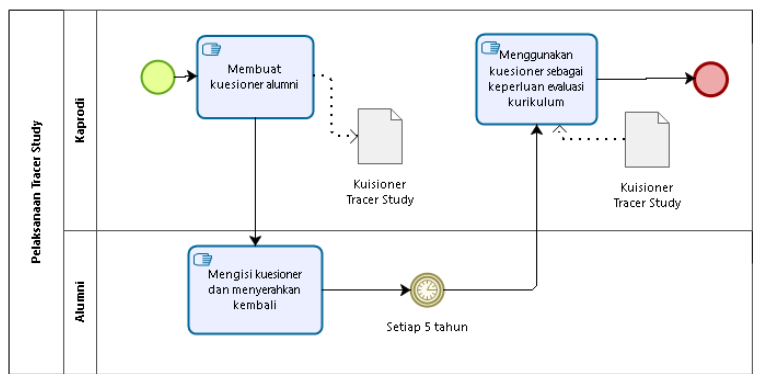

Gambar 5. Proses model as-is Pelaksanaan Tracer Study

Proses Pelaksaan Tracer Study dibagi agar memudahkan pengumpulan kuesioner, selain itu juga karena penyebaran kuesioner dilakukan terhadap entitas yang berbeda. Kuesioner pada proses model to-be juga dibuat tidak secara manual melainkan melalui sistem, sehingga memudahkan proses penyebaran kuesioner dan proses rekapitulasi kuesioner.

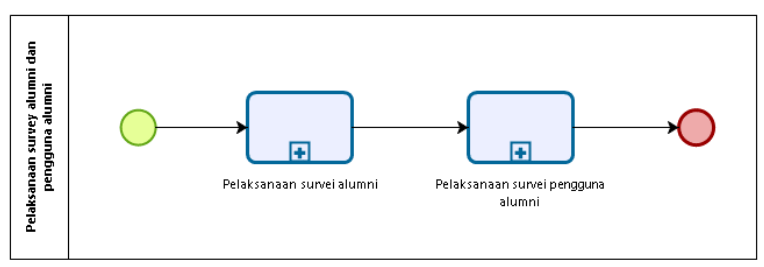




\section{Gambar 6. Proses model to-be Pelaksanaan} Survey Alumni dan Pengguna Alumni

Dari hasil kuesioner, pada proses model to-be kemudian dirapatkan dengan tim dosen. Hasil rapat tersebut kemudian dibuat upaya perbaikan terhadap kurikulum program studi dan proses pembelajaran. Rekomendasi yang telah dibuat mengacu pada standar BAN-PT nomor 3.3.1.b, yaitu penggunaan hasil pelacakan digunakan untuk perbaikan proses pembelajaran, penggalangan dana, informasi pekerjaan, dan membangun jejaring. Khusus pada penelitian ini yang fokus terhadap bidang pendidikan, upaya perbaikan hanya digunakan untuk proses pembelajaran.

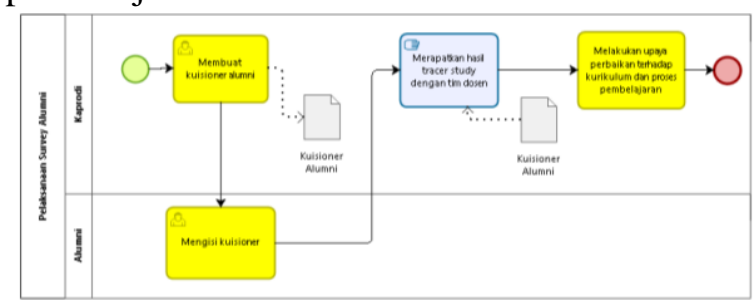

Gambar 7. Proses model to-be Pelaksanaan Survey Alumni

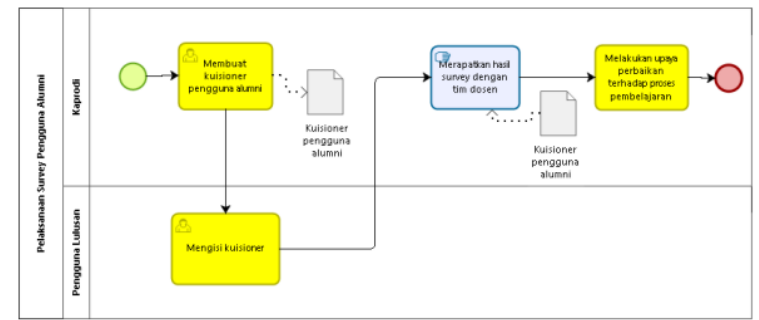

Gambar 8. Proses model to-be Pelaksanaan Survey Pengguna Alumni

Hasil dari pemodelan proses bisnis to-be didapatkan penambahan 5 proses baru, 3 proses yang ditambahkan aktivitas, 5 proses yang ditambahkan anotasi, dan 1 proses yang dihilangkan. Dari hasil process redesign didapatkan 15 proses model to-be. Verifikasi kepada ketua pusat penjaminan mutu ITK dilakukan setelah pemodelan proses bisnis to-be.

\section{KESIMPULAN}

Berdasarkan rumusan masalah yang telah dipaparkan sebelumnya dan hasil penelitian yang telah dilakukan, dapat diperoleh kesimpulan akhir penelitian sebagai berikut:

1. Proses bisnis akademik saat ini (as-is) di ITK digambarkan ke dalam bentuk model proses bisnis dengan menggunakan notasi business process model and notation (BPMN). Proses bisnis as-is terdiri atas 33 model proses bisnis yang menjelaskan proses dan sub proses. Terdapat 1 model proses utama yang menjadi gambaran umum proses bisnis akademik di ITK. Proses bisnis as-is yang dibuat telah melalui verifikasi dengan ketua pusat penjaminan mutu ITK.

2. Dari 33 model proses bisnis as-is, kemudian dilakukan analisis kesesuaian antara proses bisnis as-is dan dengan merujuk pada standar nasional pendidikan tinggi (SNPT) dan badan akreditasi nasional perguruan tinggi (BAN-PT). Kemudian dari hasil analisis didapatkan beberapa kelemahan, yaitu belum sesuai dengan standar. Terdapat 13 issue yang harus diperbaiki pada model proses bisnis as-is.

3. Pemodelan proses bisnis akademik yang akan datang (to-be) juga mengacu pada SNPT dan BAN-PT. Proses bisnis tersebut digambarkan ke dalam bentuk model proses bisnis dengan menggunakan notasi BPMN. Dari hasil analisis kesesuaian, kemudian dibuat proses model to-be dan hasilnya terdapat penambahan 5 proses baru, 3 proses yang ditambahkan aktivitas, 5 proses yang ditambahkan anotasi, dan 1 proses yang dihilangkan.

\section{DAFTAR PUSTAKA}

Ahern, D. M., Clouse, A. \& Turner, R., 2008. CMMI Distilled: A Practical Introduction to Integrated Process Improvement. s.l.:Addison-Wesley.

APQC, 2014. APQC Process Classification Framework (PCF) for Education. 3.0.1E ed. s.1.:APQC.

Badan Akreditasi Nasional Perguruan Tinggi (BAN-PT), n.d. Buku 6 - Matriks Penilaian Instrumen Akreditasi Program Studi Sarjana. s.l.:s.n.

Dumas, M., La Rosa, M., Mendling, J. \& Reijers, H. A., 2018. Fundamentals of Business Process Management. 2nd ed. Berlin: Springer.

Falahah, 2012. Analisis Dan Perbaikan Proses Bisnis Administrasi Diklat (Studi Kasus Sistem Informasi Diklat XYZ). Seminar Nasional Informatika 2012 (semnasIF 2012), pp. 45-61.

Harrington, H. J., 1991. Business Process Improvement. 2nd ed. New York: McGraw-Hill.

Kementerian Riset, T. d. P. T. R. I., 2015. Permenristedikti Nomor 44 Tahun 2015 tentang Standar Nasional Pendidikan Tinggi. Jakarta: s.n.

Kementrian Riset, Teknologi, dan Pendidikan Tinggi, 2017. Peraturan Menteri Riset, Teknologi, dan Pendidikan Tinggi Nomor 
71 tahun 2017 tentang Pedoman Penyusunan dan Evaluasi Peta Proses Bisnis dan Standar Operasional Prosedur di Lingkungan kementerian Riset, Teknologi, dan Pendidikan Tinggi, Jakarta: s.n.

Ouali, S., Mhiri, M. \& Bouzguenda, L., 2016. A Multidimensional Knowledge Model for Business Process. 20th International Conference on Knowledge Based and Intelligent Information and Engineering Systems, Volume 96, pp. 654-663.

Ramdani, M. A., 2015. Permodelan Proses Bisnis Sistem Akademik Menggunakan Pendekatan Business Process Modeling Notation (BPMN) (Studi Kasus Institusi Perguruan Tinggi XYZ). Jurnal Informasi, VII(2), pp. 83-93. 